Discussion Paper No. 14-119

\title{
The Impact of Brand Use on Innovation Performance - Empirical Results for Germany
}

Dirk Crass

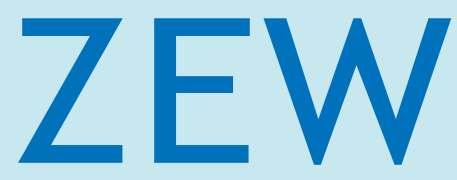

Zentrum für Europäische Wirtschaftsforschung $\mathrm{GmbH}$ Centre for European Economic Research 
Discussion Paper No. 14-119

\title{
The Impact of Brand Use on Innovation Performance - Empirical Results for Germany
}

\author{
Dirk Crass
}

Download this ZEW Discussion Paper from our ftp server:

http://ftp.zew.de/pub/zew-docs/dp/dp14119.pdf

Die Discussion Papers dienen einer möglichst schnellen Verbreitung von neueren Forschungsarbeiten des ZEW. Die Beiträge liegen in alleiniger Verantwortung der Autoren und stellen nicht notwendigerweise die Meinung des ZEW dar.

Discussion Papers are intended to make results of ZEW research promptly available to other economists in order to encourage discussion and suggestions for revisions. The authors are solely responsible for the contents which do not necessarily represent the opinion of the ZEW. 


\section{Non-technical summary}

Innovative firms aim to transfer their $R \& D$ and other related investments into successful innovations. The success of innovations requires both: the successful completion of the research and development process, resulting in a new or improved product, as well as the acceptance of the product in the market, resulting in commercial success for the firm. Following Griliches (1979), intangible capital affecting innovation success is mainly shown to be determined by the technological side. Innovation success is influenced by a firms investment in innovation, its technological capabilities, its absorptive capacities, and the use of external knowledge (Cohen and Levinthal, 1990; Crépon et al., 1998; Lööf and Heshmati, 2002; Peters and Schmiele, 2011; Peters, 2008; Hall and Mairesse, 2006).

According to this framework, new technology enables the creation of new or improved functional product attributes that speak for themselves. This is at odds with the observation that (potential) customers are not perfectly informed about quality characteristics, prices, or even the existence of product innovations. Consequently, considerable marketing activities might be necessary to overcome information asymmetries in the market. This is in line with the finding that marketing expenditures are responsible for large parts of expenditures for launching innovations (Pavitt, 1985). In other words, while a firm's technological abilities make a product innovation possible, this product may face a lack of interest among potential customers after its market introduction. Aaker (2007) points out that the branding of an innovation "can make all the difference."

This paper investigates the performance effects of branding on a firm's innovation success. First, I investigate whether the brand strategy of a firm affects the introduction of new products. Second, given that a firm has decided to introduce new product(s), I analyse whether brands are conducive to innovation success, measured in terms of sales with new products. When a firm introduces a new product, it has to make two choices. First, whether the new product is introduced with or without a brand and if it opts for a brand, whether it relies on an established brand or creates a new brand. I make use of German 2011 Community Innovation Survey (CIS), which provides a direct link between the introduction of a firm's product innovations and its use of a new or an established brand.

The results suggest that branded product innovations are more successful in terms of sales with these products. The empirical results could be driven by the unobservable quality of the firm's innovation, so that this can not be interpreted as causal effects. The use of an established brand is, however, associated to remarkable $35 \%$ higher sales with product innovations. Beyond this, firms that pursue a brand strategy, have a higher propensity to innovate in terms of the introduction of a product innovation. 


\title{
The Impact of Brand Use on Innovation Performance - Empirical Results for Germany
}

\author{
Dirk Crass *
}

December 2014

\begin{abstract}
The market launch of product innovations is the most visible output of a firm's investment in innovation activities. To achieve this objective most efficiently, firms strengthen their technological capabilities, acquire external knowledge in a number of different ways, and optimize their innovation process. The success of a firm's innovation strategy has two dimensions: First, the ability of a firm to master the research and development process, leading to the market introduction of a product innovation. Second, the ability to turn the market introduction of a product innovation into commercial success.

While a firms technological abilities make a product innovation possible, this product might face a lack of interest among potential customers after its market introduction. The introduction of a product innovation under a brand name might generate interest, adds credibility and reputation and has the potential for the firm to better appropriate the returns from its innovations. This paper investigates the role of brand use for the commercial success of product innovations, using a representative sample of German firms. The results show that firms can improve the odds of commercial success by pursuing a branding strategy. The market introduction of a product innovation is shown to be associated with $35 \%$ larger sales if the firm uses an established brand to introduce the product innovation into the market.
\end{abstract}

Keywords: innovation performance; brands; trademarks; innovation; Germany JEL Classification: O32, O34

\footnotetext{
${ }^{*}$ Centre for European Economic Research (ZEW), P.O. Box 103443, 68034 Mannheim, Germany. Phone: +49 621 1235-387, Fax: +49 621 1235-170. E-mail: crass@zew.de I would like to thank Pierre Mohnen (MERIT), Bettina Peters (ZEW), Dirk Czarnitzki (KU Leuven), and Christian Rammer for their valuable comments and discussions. Any errors remain those of the author. An overview of third-party funded projects the author was involved in is published on his personal web site: http://www.zew.de/de/mitarbeiter/dcr
} 


\section{Introduction}

Innovative firms aim to transfer their $R \& D$ and other related investments into successful innovations. The success of innovations requires both: the successful completion of the research and development process, resulting in a new or improved product, as well as the acceptance of the product in the market, resulting in commercial success for the firm. Following Griliches (1979), intangible capital affecting innovation success is mainly shown to be determined by the technological side. Innovation success is influenced by a firms investment in innovation, its technological capabilities, its absorptive capacities, and the use of external knowledge (Cohen and Levinthal, 1990; Crépon et al., 1998; Lööf and Heshmati, 2002; Peters and Schmiele, 2011; Peters, 2008; Hall and Mairesse, 2006).

According to this framework, new technology enables the creation of new or improved functional product attributes that speak for themselves. This is at odds with the observation that (potential) customers are not perfectly informed about quality characteristics, prices, or even the existence of product innovations. Consequently, considerable marketing activities might be necessary to overcome information asymmetries in the market. This is in line with the finding that marketing expenditures are responsible for large parts of expenditures for launching innovations (Pavitt, 1985). In other words, while a firm's technological abilities make a product innovation possible, this product may face a lack of interest among potential customers after its market introduction. Aaker (2007) points out that the branding of an innovation "can make all the difference." This difference, according to his reasoning, can be the result of several factors: Branding helps to "make the innovation visible" by attracting interest and recognition. Branding is furthermore able to add credibility to the product innovation and makes "communication more efficient". The branding of product innovations also provides "the potential to own the innovation". A competitor might offer an imitation of the product innovation, but "will need to overcome the power of the brand" (Aaker, 2007). In this sense, branding can be an effective strategy to appropriate the returns of an innovation (Amara et al., 2008). To sum up, branding might play a crucial role during the commercialisation and might have an important impact on the economic success of a firm's product innovation.

The aim of this paper is to investigate the performance effects of branding on a firm's innovation success. First, I investigate whether the brand strategy of a firm affects the introduction of new products. Second, given that a firm has decided to introduce new product(s), I analyse whether brands are conducive to innovation success, measured in terms of sales with new products. When a firm introduces 
a new product, it has to make two choices. First, whether the new product is introduced with or without a brand and if it opts for a brand, whether it relies on an established brand or creates a new brand.

Previous studies provide evidence that brands improve a firm's market valuation, productivity and profitability (Sandner and Block, 2011; Crass and Peters, 2014; Griffiths et al., 2011; Crass et al., 2014). To the best of my knowledge, there is no large-scale evidence about the impact of brands on the commercial performance of product innovations. The impact of well-known brands like Coca-Cola, Apple, Google, or Mercedes on the commercial performance of corresponding product innovations supports a positive impact. These global brands are, however, not necessarily representative for the entire economic sector. Do firms on average profit from a branding strategy? This study aims to provide empirical evidence to fill the research gap on the impact of brands on innovation performance by using a representative sample of German firms.

Firm-level data is obtained from the Mannheim Innovation Panel (MIP), which is the official innovation Survey in Germany, based on a stratified random sample of legally independent firms in the business sector with at least five employees. In addition to various innovation indicators, the 2011 survey provides unique information on firms' branding strategies. Firms were asked whether their product innovations were introduced without a brand, under an established brand or a new brand. MIP firmlevel data is furthermore augmented by information on firms' trademark registrations at the German as well as the European trademark office.

Results show that firms achieve larger performance effects with branded product innovations than with unbranded ones. Beyond this, firms that pursue a brand strategy, have a higher propensity to innovate in terms of the introduction of a product innovation.

\section{Determinants of Innovation Performance}

Innovation performance has several dimensions and can be measured quite differently. Common measures of innovation output are patent applications, the introduction of product and process innovations, cost reductions due to process innovations and the share of sales with innovative products. Patents are indicators for the success of a firm's research activities. A patent indicates that a firm has achieved a new technical invention, that is commercially applicable and has a sufficient level of inventiveness. These inventions are not equivalent to new products. A technological invention becomes a product innovation only if "it has processed through production and marketing tasks and is diffused into the marketplace" (Garcia and 
Calantone, 2002). However, product innovations do not have to be based on patents. In fact, just $31 \%$ of German firms with product or process innovations used patents to protect their intellectual property (Aschhoff et al., 2013). The introduction of a product innovation constitutes an indicator of innovation success, which emphasizes in particular the commercially useful output. The commercial success is measured through a firm's sales share with its product innovations. The share of innovative sales in total turnover captures, in contrast to traditional patent indicators, "a direct link between the innovation effort and commercial success" (Chudnovsky et al., 2006).

Each product innovator thus has to manage both: the development of a new product, possibly based on a technological invention as well as the commercial success of the product innovation in the marketplace. Both stages are risky and only a fraction of product launches are successful (Hauser et al., 2006). Firms are interested in maximizing their chances of success. In the following I discuss factors that are supposed to enhance the probability of success.

\subsection{Investment in Innovation}

One of the most important determinants of innovation performance is the extent to which a firm invests in innovation (Crépon et al., 1998; Mairesse and Mohnen, 2002; Griffith et al., 2006). The greater a firm's efforts in innovation activities, the larger the probability of having a product innovation and the larger on average the innovation performance.

The acquisition of external knowledge is crucial to improve a firm's innovation performance. Internal R\&D activities are more efficient, if they are combined with external sources. Cassiman and Veugelers (2006) provide empirical evidence for the complementarity of internal R\&D and external knowledge-acquisition activities. They show that external R\&D, that is $R \& D$ that is contracted out to third parties has a positive effect on the marginal return of internal $R \& D$, and vice versa. However, outsourcing of $R \& D$ can also have a negative impact on innovation performance. Grimpe and Kaiser (2010) argue that "over-outsourcing" constitutes a serious risk to a firm's innovation success but the negative effects can be mitigated through the extent of internal R\&D and the breadth of research collaborations. This finding emphasizes the importance of balancing internal and external innovation activities to maintain a firm's "absorptive capacity" (Cohen and Levin, 1989), which is based on its stock of prior knowledge. These findings also point to cooperation as another source of external knowledge.

Research and development (R\&D) alliances opens a wide range of external knowl- 
edge sources. A firm might cooperate with competitors, suppliers, customers, and universities and research institutes to acquire relevant external knowledge for the innovation process. Laursen and Salter (2006) emphasize the role of a firm's search strategy for new ideas that have a high potential for commercial success. They find that firms who are more open to external sources have more commercial success with their product innovations. Many firms are involved in multiple cooperation alliances. Synergy effects and complementary knowledge from different sources can increase the impact on innovation success (Belderbos et al., 2004; Leiponen and Helfat, 2010). The diversity of cooperation partners increases the effect of R\&D alliances (van Beers and Zand, 2014).

Given that many product innovations fail, a firm is most successful if it pursues several innovation projects (Hauser et al., 2006). The underlying idea is quite simple: Pursuing several innovation projects increases the probability that at least one of them will be successful. Klingebiel and Rammer (2014) investigate the effect of different resource allocation strategies on innovation performance. They find that breadth in resource allocation increases innovation performance, that is the more projects, the higher is the likelihood of some innovation success. According to their findings, firms achieve greater performance if they allocate their financial resources initially to a broad range of projects and discontinue less successful projects in later stages, leading to the selection of the most successful projects.

To sum up, prior literature has shown that innovation performance is influenced by the investment in research and development, the various ways to acquire knowledge, and the way to design the innovation process. Apart from these closely innovationrelated factors, a number of other factors are found to be relevant. Hall et al. (2013) find, for example, that investment in information and communication technology (ICT) is strongly associated with innovation success. They treat ICT in parallel with $\mathrm{R} \& \mathrm{D}$ as an input to innovation and find both to contribute to a firm's innovation performance.

Another crucial asset for firm performance is brand equity. Brand equity is shown to add to the overall performance of a firm, particularly in terms of productivity, profitability and market value (Srinivasan et al., 2011; Griffiths et al., 2011; Sandner and Block, 2011; Crass and Peters, 2014; Crass et al., 2014), but its contribution to innovation performance is empirically less clear.

\subsection{Brand Use}

Once the firm has managed to achieve market readiness of a new or significantly improved product, the firm has to decide whether it introduces the product innova- 
tion under a brand and if so, whether it makes use of a new or an established brand. The market introduction under a brand might enhance the economic success of the product innovation. The brand could even make "all the difference" (Aaker, 2007). This might be due to the fact that a brand generates attention to the product innovation, adds reputation and credibility, and helps to appropriate the returns from the innovation.

Independently of how well a product innovation might meet the needs of customers, they have to be aware of it to purchase it (Srinivasan et al., 2005). Branding helps to make the innovation visible by attracting interest and recognition (Aaker, 2007). In this sense, the product innovation can achieve higher awareness and is easier to remember.

A product innovation has per definition significant new features or is even completely new. The target audience has no experience with the particular product innovation and might face uncertainty about its (new) features. The good experience that consumers may have had with previous purchases of the brand is likely to induce them to transmit their confidence in the brand to the product innovation. Established brands are thus able to add reputation and credibility to new products.

An established brand differs from a new brand in its already established reputation among the target audience. Building a new brand takes time and is associated with considerably costs. The use of a new brand to introduce new products into the market might therefore be less powerful and positive effects might occur not immediately but only in the medium and long term. The use of an established brand to introduce a new product has advantages, since its reputation and awareness can be attached to a new product immediately, the chances of success are higher and marketing costs are lower. A firm might, regardless of the advantages of an established brand, decide to use a new brand. Apart from the possibility that the firm does not have an established brand, there are two main reasons to use a new brand. First, an established brand can fail to help a new product. This might be the case if the new product does not fit to the perceptions of the consumers about the established brand. Second, a new product can damage the original brand by adding undesired associations (Aaker, 1991; Srinivasan et al., 2011).

Most product innovations can be imitated by competitors. If the product innovation is linked in the minds of the consumers to the brand, then the brand becomes an integral feature of the product itself. In this case, a competitor not only has to imitate the product, but also to overcome the power of the brand (Aaker, 2007). Since a firm can protect its brands by trademarks, which can be renewed indefinitely, the power of the brand might constitute a long-term competitive advantage over 
competitors. ${ }^{1}$ This means that the branding of a product innovation provides the potential to better appropriate the returns from innovation because the innovator can achieve a legally protected monopoly over its brand. Hence I expect firms which use brands for product innovations to have a higher innovation success.

\section{Data and Variables}

\subsection{Data Sets}

Most of the firm-level data come from the Mannheim Innovation Panel, which constitutes the German contribution to the European Community Innovation Survey (CIS). The survey is a stratified random sample (by sector, size, and region) that targets the population of all German firms with at least five employees in manufacturing and service industries. The survey is conducted annually since 1993 by the Centre for European Economic Research (ZEW) in collaboration with infas Institute for Applied Social Sciences and the Fraunhofer Institute for Systems and Innovation Research (ISI) on behalf of the feral ministry of education and research. It asks firms to report general and innovation related information covering the prior three years. So, for instance, the 2011 survey used here collected data for 2008, 2009, and 2010. (OECD, Eurostat, 2005). CIS methodology and questionnaires are internationally harmonized across the countries and based on the so-called Oslo Manual (OECD, Eurostat, 2005). German CIS data provide an additional layer of quality through extensive nonresponse surveys and are considered to be of high quality (Eurostat, 2013). Further information on the survey methodology, data, and validity is provided by Peters (2008), Aschhoff et al. (2013), and Peters and Rammer (2013). This study combines the German CIS information of the 2011 survey with administrative data on each firm's trademark and patenting activity. The trademark data comes from the Office for Harmonization in the Internal Market (OHIM) and the German Patent and Trade Mark Office (DPMA). The OHIM data reflect trademarks valid in all European Union (EU) member states while the DPMA trademarks are specific to Germany. The patent data come from the European Patent Office (EPO) and Germany's DPMA. All administrative data were matched to the German CIS using assignee name and address information and specialized software developed at the Centre for European Economic Research.

The sample consists of 6,844 firms for which information of their innovation activities is available. The German part of the Community Innovation Survey (CIS) offers

\footnotetext{
${ }^{1}$ The owner of a trademark is given a legal monopoly over the protected word, sign, symbol or other graphical representation in connection with the attached commodity (Economides, 1998; Baroncelli et al., 2004).
} 
some flexibility for additional questions in addition to the core questions of the harmonized CIS questionnaire. This flexibility was used in 2011 to include a set of questions on a firm's branding strategy.

\subsection{Product Innovation Performance}

The first dependent variable is a binary indicator for product innovators i.e. firms that have managed to introduce a product innovation into the market between 2008 and 2010. The commercial success of these product innovations is captured through a firm's revenue derived from new product sales in 2010. This second measure reflects the acceptance of the innovation in the market and provides a direct link between product innovations and their commercial performance (Chudnovsky et al., 2006; Mairesse and Mohnen, 2010).

A product innovation is defined as the market introduction of a new or significantly improved good or service, which is either new or significantly improved with respect to its fundamental characteristics or technical components. The innovation has to be new to the firm, not necessarily new to the market. This definition captures quite different degrees of innovativeness, which can be further distinguished between market novelties (new-to-the-market products) and firm novelties (product imitations). Market novelties are product innovations that have been launched onto the market by a firm prior to any competitor. Imitative product innovations are defined to be new to the firm, but not new to the market (Garcia and Calantone, 2002). The survey design furthermore allows to distinguish between firm's revenue from new-to-market product sales and new-to-firm (imitative) product sales. The questionnaire provides the percentage of firm sales derived from the introduction of product innovations, as well as the percentage of new-to-market product sales in 2010. The difference between these two values is, by definition, the percentage of imitative product innovations.

Several studies have used the share of sales with product innovations as dependent variable (Crépon et al., 1998; Chudnovsky et al., 2006; Mairesse and Mohnen, 2010; Grimpe and Kaiser, 2010). One can argue that with respect to the dependent variable more should always be better. However, a higher percentage of sales with innovative products does not automatically imply better performance. Particularly smaller and single product firms quickly achieve high intensities. Klingebiel and Rammer (2014) therefore propose the use of raw values. The percentage shares are multiplied by a firm's total sales, to obtain the raw Euro value of a firm's product innovation sales. This study follows their suggestion and uses the percentage shares only as a robustness-check. 
About $38 \%$ of the sample firms introduced at least one product innovation between 2008 and 2010. About 18\% introduced at least one market novelty and $32 \%$ at least one product imitation. The innovators in the sample generate on average 26.8 percent of total turnover with new or improved products. About 7.6 percent of total turnover result from new-to-market product innovations and the remaining 19.2 percent from product imitations.

\subsection{The Use of Brands for Product Innovations}

As explained in the previous section, brands might play an important role in the commercialization phase of product innovations. The CIS 2011 survey provides unique information about the branding strategy related to product innovation. In addition to the core CIS questions, German firms were asked to report whether its product innovations were introduced without a brand, under an established brand or a new brand. Three dummy variables have been constructed, which indicate whether a firm's product innovation was introduced under an established brand, under a new brand or (the reference category) without any branding.

Table 1: Brand Usage of Product Innovators

\begin{tabular}{lccc}
\hline Sector & Establ. Brand & New Brand & No Brand \\
\hline Mining & 0.00 & 0.20 & 0.80 \\
Low-tech manufacturing & 0.26 & 0.15 & 0.61 \\
High-tech manufacturing & 0.34 & 0.19 & 0.52 \\
Energy, water, recycling & 0.15 & 0.09 & 0.79 \\
Construction & 0.20 & 0.00 & 0.80 \\
Wholesale & 0.42 & 0.15 & 0.42 \\
Transportation & 0.10 & 0.04 & 0.87 \\
Information and Communication & 0.29 & 0.13 & 0.62 \\
Financial Services & 0.10 & 0.05 & 0.85 \\
Consulting, Advertising & 0.17 & 0.05 & 0.78 \\
Engineering/R\&D services & 0.15 & 0.07 & 0.80 \\
Other business services & 0.09 & 0.02 & 0.89 \\
\hline Total & 0.26 & 0.14 & 0.62 \\
\hline
\end{tabular}

Source: ZEW: Mannheim Innovation Panel, survey 2011.

Table 1 depicts descriptive statistics on the usage of branding strategies related to the introduction of new products. It turns out that the majority, $62 \%$ of product innovators, do not rely on brands at all when they introduce new products into the marketplace. About $14 \%$ of the product innovators attempt to introduce a product innovation under a new brand and $26 \%$ rely on an established brand. Only a small 
group of $2.5 \%$ of the firms use both, new and established brands. A differentiation by sector affiliation shows a high degree of heterogeneity of brand usage across different industries. Branding of product innovations is most common in the wholesale sector, where around $60 \%$ of the product innovators use a brand name for their innovations, followed by the high-tech manufacturing sector (with around 50\%), the low-tech manufacturing sector and the information and communication sector (both with around 40\%). Branding of product innovations has only a minor importance within the so-called other business service sector (only about $10 \%$ use a brand name), the transportation sector (14\%) and the financial service sector (16\%).

Brands can be protected by trademarks. The data about trademark registration have the advantage that they provide information on past brand-related activities. The binary variable trademark makes use of the information on a firm's trademark history and takes the value 1 , if the firm has at least one registered trademark in 2007. The year 2007 refers to the year prior to the period 2008 to 2010 in which the product innovation is captured.

Brands are built over time through a variety of management choices such as expenditures on advertising, promotions, market research, loyalty programs, distribution channel development, product-quality and customer service efforts, and new product development (Kirk et al., 2013). Marketing expenditures capture an important part of these expenses, including all in-house and contracted out expenditures for advertising and branding, reputation building, conceptual design of marketing strategies, market and costumer research, and the installation of new distribution channels. A firm's marketing intensity is measured as a firm's marketing expenditure per employee.

\subsection{Control variables}

The model contains a number of control variables that might influence innovation performance and are frequently used as explanatory variables (Crépon et al., 1998; Grimpe and Kaiser, 2010; Klingebiel and Rammer, 2014; Mairesse and Mohnen, 2002). The number of employees (in logs) accounts for firm size and sales per employee for a firm's level of productivity in 2008. One of the most important determinants of innovation performance is innovation effort. The more a firm spends on innovation, the more product and process innovations might be developed. Innovation intensity, measured as the total amount of innovation expenditure per employee, is therefore included as additional control variable in order to account for differences in innovation effort. The dummy variable process innovation indicates whether innovation expenditures are at least partly assigned to process innovations. 
The stock of prior knowledge creates the basis for a firm's "absorptive capacity" (Cohen and Levin, 1989), which is captured through a firm's patent stock and a dummy variable, indicating continuous $R \mathscr{E} D$ activities. $R \& D$ is conducted on a continuous base by about half of the product innovating firms. Whether a firm does R\&D continuously is direct information from the survey. The patent stock is calculated from the annual time series of patent applications at the European Patent Office using the perpetual inventory method with a discount factor of 0.15 (Griliches and Mairesse, 1984; Hall, 1999). Roughly one out of five product innovater (23\%) have patent applications. Taking the logarithm of the patent stock yields missing values for all observations with no patents at all. The value of these missings is set to zero and a dummy variable indicating a firm without patents is added in the regression. The acquisition of external knowledge is captured by two dummy variables. The first dummy variable external $R \mathscr{E} D$ indicates that a firm contracts $R \& D$ out and the second dummy variable cooperation indicates that a firm has innovation alliances with competitors, suppliers, customers, or universities and research institutes.

Human capital is an important input factor in a firm's innovation process. High skilled labour, the proportion of employees with a university degree, captures an important dimension of human capital in firms. About $25 \%$ of the employees of product innovating firms have a university degree, while this proportion is considerably smaller for non-product innovators at about $15 \%$. The typical length of a firm's product life cycle is supposed to have an influence on the frequency of a firm's market introductions. The shorter the typical life cycle of products is, the larger should be the sales share with its product innovations. To control for the typical life cycle, I make use of a firm's assessment of whether its products are quickly outdated. The survey asked respondents to state on a four-point Likert scale (zero=does not apply at all, to three=does apply fully) whether the firm's most important products and services are quickly outdated. The variable quickly outdated represents the industry average of firms that have marked the highest category.

I also control for several basic firm characteristics. Firm age is measured as the $\log$ of years since the firm's foundation. A region dummy indicates whether the firm's headquarter is located in East Germany and an exporter dummy whether the firm serves international markets. Firms which belong to a group of companies can make use of the resources of the group and thus gain from synergy (dis)advantages. Increased intragroup synergies can lead to higher innovation output. An indicator variable group is therefore included. Furthermore, I include 12 industry dummies to control for industry characteristics that are not measured by the other structural variables. Firms are assigned to these industries on the basis of their most important activity. Detailed descriptions of the variables are provided in Table 6 in the 
Table 2: Descriptive Statistics of Main Variables

\begin{tabular}{|c|c|c|c|c|c|c|}
\hline & \multicolumn{2}{|c|}{$\begin{array}{c}(1) \\
\text { Full sample }\end{array}$} & \multicolumn{2}{|c|}{$\begin{array}{c}(2) \\
\text { Innovators }\end{array}$} & \multicolumn{2}{|c|}{$\begin{array}{c}(3) \\
\text { Innov. vs. Non-Innov. }\end{array}$} \\
\hline & Mean & $\mathrm{SE}$ & Mean & SE & Diff & $\mathrm{SE}$ \\
\hline Product Innovation (D) & 0.38 & $(0.01)$ & 1.00 & $(0.00)$ & 1.00 & $(0.00)$ \\
\hline Sales Product Innovations & 6.41 & $(1.24)$ & 17.25 & $(3.31)$ & $17.25^{* * *}$ & $(2.54)$ \\
\hline Sales Share Innovations & 10.05 & $(0.32)$ & 26.80 & $(0.66)$ & $26.80^{* * *}$ & $(0.51)$ \\
\hline Market Novelty (D) & 0.18 & $(0.01)$ & 0.49 & $(0.01)$ & $0.49^{* * *}$ & $(0.01)$ \\
\hline Sales Market Novelties & 1.40 & $(0.23)$ & 3.77 & $(0.61)$ & $3.77^{* * *}$ & $(0.47)$ \\
\hline Sales Share Market Novelties & 2.84 & $(0.16)$ & 7.57 & $(0.41)$ & $7.57^{* * *}$ & $(0.31)$ \\
\hline Imitative Innovation (D) & 0.32 & $(0.01)$ & 0.84 & $(0.01)$ & $0.84 * * *$ & $(0.01)$ \\
\hline Sales Product Imitations & 5.01 & $(1.12)$ & 13.48 & $(3.00)$ & $13.48^{* * *}$ & $(2.30)$ \\
\hline Sales Share Imitation Product & 7.21 & $(0.26)$ & 19.22 & $(0.58)$ & $19.22^{* * *}$ & $(0.45)$ \\
\hline Innovation intensity & 0.00 & $(0.00)$ & 0.01 & $(0.00)$ & $0.01^{* * *}$ & $(0.00)$ \\
\hline High Skilled Labour & 18.35 & $(0.37)$ & 24.28 & $(0.68)$ & $9.49 * * *$ & $(0.76)$ \\
\hline Process Innovation (D) & 0.29 & $(0.01)$ & 0.52 & $(0.01)$ & $0.37 * * *$ & $(0.01)$ \\
\hline Patent stock (ln) & 0.00 & $(0.01)$ & 0.08 & $(0.02)$ & $0.13^{* * *}$ & $(0.02)$ \\
\hline Patent stock: zero & 0.88 & $(0.01)$ & 0.77 & $(0.01)$ & $-0.18^{* * *}$ & $(0.01)$ \\
\hline Continuous R\&D (D) & 0.21 & $(0.01)$ & 0.48 & $(0.01)$ & $0.43^{* * *}$ & $(0.01)$ \\
\hline External R\&D (D) & 0.15 & $(0.01)$ & 0.32 & $(0.01)$ & $0.27^{* * *}$ & $(0.01)$ \\
\hline Cooperation (D) & 0.21 & $(0.01)$ & 0.25 & $(0.01)$ & $0.06^{* * *}$ & $(0.01)$ \\
\hline Marketing intensity & 0.00 & $(0.00)$ & 0.00 & $(0.00)$ & $0.00 * * *$ & $(0.00)$ \\
\hline Established Brand (D) & 0.10 & $(0.00)$ & 0.26 & $(0.01)$ & $0.26^{* * *}$ & $(0.01)$ \\
\hline New Brand (D) & 0.05 & $(0.00)$ & 0.14 & $(0.01)$ & $0.14^{* * *}$ & $(0.01)$ \\
\hline Trademark (D, L3) & 0.29 & $(0.01)$ & 0.44 & $(0.01)$ & $0.24^{* * *}$ & $(0.01)$ \\
\hline Diversity (ln) & -4.19 & $(0.01)$ & -4.13 & $(0.01)$ & $0.10^{* * *}$ & $(0.01)$ \\
\hline divln_m & 0.07 & $(0.00)$ & 0.05 & $(0.01)$ & $-0.03^{* * *}$ & $(0.01)$ \\
\hline Market share (ln, L2) & -0.75 & $(0.07)$ & -0.13 & $(0.11)$ & $0.99 * * *$ & $(0.14)$ \\
\hline Missing: Market share (ln, L2) & 0.21 & $(0.01)$ & 0.16 & $(0.01)$ & $-0.08^{* * *}$ & $(0.01)$ \\
\hline Firm Size (ln \# of employees) & 3.68 & $(0.02)$ & 3.97 & $(0.04)$ & $0.46^{* * *}$ & $(0.05)$ \\
\hline Productivity (L2) & 0.20 & $(0.01)$ & 0.19 & $(0.02)$ & -0.01 & $(0.02)$ \\
\hline Exporter (D) & 0.46 & $(0.01)$ & 0.67 & $(0.01)$ & $0.34^{* * *}$ & $(0.02)$ \\
\hline Firm age & 3.15 & $(0.01)$ & 3.09 & $(0.02)$ & $-0.10^{* * *}$ & $(0.03)$ \\
\hline Quickly Outdated & 0.06 & $(0.00)$ & 0.07 & $(0.00)$ & $0.01^{* * *}$ & $(0.00)$ \\
\hline Group (D) & 0.28 & $(0.01)$ & 0.34 & $(0.01)$ & $0.10^{* * *}$ & $(0.01)$ \\
\hline East Germany (D) & 0.34 & $(0.01)$ & 0.32 & $(0.01)$ & $-0.03^{*}$ & $(0.02)$ \\
\hline
\end{tabular}

The first column provides mean and standard error of the main variables for the full sample, the second column for the subsample of product innovating firms, and the third column provides the difference between product innovating and non-product-innovating firms.

Notes: (D) denotes dummy variables. (L2) denotes two, and (L3) three year lagged variables. Source: ZEW: Mannheim Innovation Panel, survey 2011. 
Appendix. 


\section{Empirical Strategy and Results}

The study aims at shedding light on the question how brands impact innovation performance. Innovation performance, however, can be observed only for those firms that have accomplished the market introduction of a new or significantly improved product. This group of product innovators is not randomly assigned, which is why we have to address a potential selection bias. A Heckman sample selection model, which is also referred to as Tobit type II model, is estimated to control for selection bias. The model is specified with two equations: the first one explains the propensity to introduce a product innovation. Given that a firm has introduced a new product, the second equation explains the innovation performance in terms of sales with these product innovations.

In the first stage I investigate the determinants that lead to product innovations. Firms have to decide to invest in innovation and have to be successful in accomplishing the innovation process to introduce a new or significantly improved product. Following the literature of a firm's propensity to launch a product innovation (e.g. Crépon et al., 1998; Klingebiel and Rammer, 2014), the following explanatory variables are included: firm size, lagged level of firm productivity, firm age, a firm's absorptive capability (measured by its lagged patent stock and the share of high skilled labour), the market environment (captured by the assessment whether its products are quickly outdated and whether the firm serves international markets), and whether the firm belongs to a group. Product innovations might be caused by brands (Crass, 2014). To mitigate potential endogeneity problems, I include the three-year lagged trademark indicator in the selection regression.

The specification of the selection equation should include a so-called exclusion restriction, so that the identification of the model is not based solely upon the nonlinearity in the functional form (Cameron and Trivedi, 2009). A variable which serves as exclusion restriction provides an independent source of variation in the probability to introduce innovations and does not affect innovation performance directly. A firm's market share and the degree of a firm's product diversity meet these requirements. The larger a firm's market share, the more likely it is that a firm introduces a new product while the market share does not affect the absolute amount of innovative sales. Indeed, when we additionally include market share in the second stage, we do not find a significant impact though this is not a formal test of the validity as exclusion restriction. Likewise, I expect the degree of product diversity to have an impact on the propensity to introduce a product innovation, since a more diverse firm has more "chances" to improve its products and services. Product diversity has, however, no impact on the economic success of product innovations (Crépon et al., 
1998). This qualifies product diversity to serve as exclusion restriction as well. In the second stage, the factors influencing the innovation performance of a firm's product innovations are investigated. As the main variables of interest I add a dummy variable, which indicates the use of a brand when pacing a product innovation onto the market. The use of a brand is in the next step distinguished by two dummy variables, which indicate the introduction of a firm's product innovations under an established brand and under a new brand. Innovative success might not only be affected by the use of brands but also by marketing efforts. Even without brand usage firms can spend on marketing activities. However, firms might be more dedicated to marketing activities if they use brands. In order to separate the effect of branding from marketing expenditures, I additionally include marketing intensity. A firm's innovation activities include its innovation intensity, a dummy variable indicating that the firm conducts $R \& D$ on a continuous basis, that the firm could potentially acquire external knowledge through the outsourcing of $\mathrm{R} \% \mathrm{D}$ or $\mathrm{R} \& \mathrm{D}$ cooperation. If a firm introduces a process innovation, innovation expenditures are attributed to a certain extent to process innovations. This is why a dummy variable controls for the introduction of process innovations.

The model includes also the explanatory variables from the first stage, with the exception of a firm's degree of product diversity and its market share (which serve as exclusion restriction) and the dummy variable, indicating that the firm has at least one registered trademark in 2007.

\subsection{Impact of Brand Use on Innovation}

Table 3 presents the full maximum likelihood estimates of the above described Heckman model. Since this study makes use of cross sectional data, the results should be interpreted as associations rather than causal effects. The specification is gradually enriched by including marketing and brand use. Columns (1), (3), (5), (7) present results on the total amount of innovative sales for the second stage of the estimation procedure. Columns (2), (4), (6), (8) report the corresponding first stage results of the selection equation.

Column (1) and (2) present the estimates of the basic specification using common innovation related variables but without including any brand or marketing related ones. The results of the selection equation, presented in Column (2), confirm prior findings from the literature. The propensity to introduce a product innovation increases with firm size, a firm's technological capabilities, captured through its patent stock and the proportion of high skilled labour. Furthermore, results show that older firms are less likely to introduce innovations than younger ones and the 
Table 3: The Propensity to Innovate and Determinants of Innovation Performance

\begin{tabular}{|c|c|c|c|c|c|c|c|c|}
\hline & $\begin{array}{c}(1) \\
\text { Sales }\end{array}$ & $\begin{array}{c}(2) \\
\text { yes } / \text { no }\end{array}$ & $\begin{array}{c}(3) \\
\text { Sales }\end{array}$ & $\begin{array}{c}(4) \\
\text { yes/no }\end{array}$ & $\begin{array}{c}(5) \\
\text { Sales }\end{array}$ & $\begin{array}{c}(6) \\
\text { yes/no }\end{array}$ & $\begin{array}{c}(7) \\
\text { Sales }\end{array}$ & $\begin{array}{c}(8) \\
\text { yes } / \text { no }\end{array}$ \\
\hline Firm Size (ln \# empl.) & $\begin{array}{l}0.940 * * * \\
(0.029)\end{array}$ & $\begin{array}{l}0.067^{* * *} \\
(0.020)\end{array}$ & $\begin{array}{l}0.929 * * * \\
(0.029)\end{array}$ & $\begin{array}{c}0.050^{* *} \\
(0.020)\end{array}$ & $\begin{array}{l}0.929 * * * \\
(0.029)\end{array}$ & $\begin{array}{c}0.050^{* *} \\
(0.020)\end{array}$ & $\begin{array}{l}0.932^{* * *} \\
(0.029)\end{array}$ & $\begin{array}{c}0.050^{* *} \\
(0.020)\end{array}$ \\
\hline Productivity (L2) & $\begin{array}{l}0.488^{* * *} \\
(0.052)\end{array}$ & $\begin{array}{l}-0.002 \\
(0.039)\end{array}$ & $\begin{array}{l}0.471^{* * * *} \\
(0.051)\end{array}$ & $\begin{array}{c}-0.013 \\
(0.039)\end{array}$ & $\begin{array}{l}0.470^{* * *} \\
(0.051)\end{array}$ & -0.013 & $\begin{array}{l}0.469 * * * \\
(0.051)\end{array}$ & $\begin{array}{c}-0.013 \\
(0.039)\end{array}$ \\
\hline Marketing Intensity & & & $\begin{array}{l}30.358^{* * *} \\
(5.532)\end{array}$ & & $\begin{array}{l}29.387^{* * *} \\
(5.522)\end{array}$ & & $\begin{array}{l}39.941^{* * *} \\
(9.603)\end{array}$ & \\
\hline Brand Use & & & $\begin{array}{l}0.241^{* * *} \\
(0.070)\end{array}$ & & & & & \\
\hline Established Brand (D) & & & & & $\begin{array}{l}0.346^{* * *} \\
(0.075)\end{array}$ & & $\begin{array}{l}0.380^{* * *} \\
(0.079)\end{array}$ & \\
\hline Est. Brand x Market. & & & & & & & $\begin{array}{l}-16.236 \\
(11.517)\end{array}$ & \\
\hline New Brand (D) & & & & & $\begin{array}{c}0.011 \\
(0.095)\end{array}$ & & $\begin{array}{c}0.001 \\
(0.105)\end{array}$ & \\
\hline New Brand x Market. & & & & & & & $\begin{array}{c}1.964 \\
(16.905)\end{array}$ & \\
\hline Trademark (D, L3) & & & & $\begin{array}{l}0.238^{* * *} \\
(0.056)\end{array}$ & & $\begin{array}{l}0.238^{* * *} \\
(0.056)\end{array}$ & & $\begin{array}{l}0.238^{* * *} \\
(0.056)\end{array}$ \\
\hline Innovation Intensity & $\begin{array}{l}4.933^{* * *} \\
(1.344)\end{array}$ & & $\begin{array}{l}3.661^{* * *} \\
(1.338)\end{array}$ & & $\begin{array}{l}3.513^{* * *} \\
(1.334)\end{array}$ & & $\begin{array}{c}3.670^{* * *} \\
(1.347)\end{array}$ & \\
\hline High Skilled Labour & $\begin{array}{l}0.006^{* * *} \\
(0.002)\end{array}$ & $\begin{array}{l}0.009 * * * \\
(0.001)\end{array}$ & $\begin{array}{l}0.005^{* * *} \\
(0.002)\end{array}$ & $\begin{array}{l}0.008^{* * *} \\
(0.001)\end{array}$ & $\begin{array}{l}0.005^{* * *} \\
(0.002)\end{array}$ & $\begin{array}{l}0.008^{* * *} \\
(0.001)\end{array}$ & $\begin{array}{l}0.005^{* * *} \\
(0.002)\end{array}$ & $\begin{array}{l}0.008^{* * *} \\
(0.001)\end{array}$ \\
\hline Process Innovation (D) & $\begin{array}{l}0.178^{* * *} \\
(0.066)\end{array}$ & & $\begin{array}{l}0.176^{* * *} \\
(0.065)\end{array}$ & & $\begin{array}{l}0.173^{* * *} \\
(0.064)\end{array}$ & & $\begin{array}{l}0.176^{* * *} \\
(0.064)\end{array}$ & \\
\hline Patent Stock (ln, L1) & $\begin{array}{l}0.089^{* *} \\
(0.040)\end{array}$ & $\begin{array}{l}0.178^{* * *} \\
(0.042)\end{array}$ & $\begin{array}{r}0.072^{*} \\
(0.039)\end{array}$ & $\begin{array}{l}0.174^{* * *} \\
(0.042)\end{array}$ & $\begin{array}{r}0.067^{*} \\
(0.039)\end{array}$ & $\begin{array}{l}0.174^{* * *} \\
(0.042)\end{array}$ & $\begin{array}{c}0.066^{*} \\
(0.039)\end{array}$ & $\begin{array}{l}0.174^{* * *} \\
(0.042)\end{array}$ \\
\hline Continuous R\&D (D) & $\begin{array}{c}0.096 \\
(0.076)\end{array}$ & & $\begin{array}{c}0.106 \\
(0.075)\end{array}$ & & $\begin{array}{c}0.111 \\
(0.075)\end{array}$ & & $\begin{array}{c}0.105 \\
(0.075)\end{array}$ & \\
\hline External R\&D (D) & $\begin{array}{c}0.045 \\
(0.076)\end{array}$ & & $\begin{array}{c}0.032 \\
(0.075)\end{array}$ & & $\begin{array}{c}0.028 \\
(0.075)\end{array}$ & & $\begin{array}{c}0.028 \\
(0.075)\end{array}$ & \\
\hline Cooperation (D) & $\begin{array}{l}-0.008 \\
(0.075)\end{array}$ & & $\begin{array}{l}-0.012 \\
(0.074)\end{array}$ & & $\begin{array}{l}-0.004 \\
(0.074)\end{array}$ & & $\begin{array}{c}-0.000 \\
(0.074)\end{array}$ & \\
\hline Exporter (D) & $\begin{array}{l}0.301^{* * *} \\
(0.093)\end{array}$ & $\begin{array}{l}0.453^{* * *} \\
(0.055)\end{array}$ & $\begin{array}{l}0.250^{* * *} \\
(0.092)\end{array}$ & $\begin{array}{l}0.427^{* * *} \\
(0.055)\end{array}$ & $\begin{array}{l}0.252^{* * *} \\
(0.091)\end{array}$ & $\begin{array}{l}0.427^{* * *} \\
(0.055)\end{array}$ & $\begin{array}{l}0.250^{* * *} \\
(0.091)\end{array}$ & $\begin{array}{l}0.427^{* * *} \\
(0.055)\end{array}$ \\
\hline Firm Age & $\begin{array}{l}-0.140^{* * *} \\
(0.043)\end{array}$ & $\begin{array}{l}-0.135^{* * *} \\
(0.030)\end{array}$ & $\begin{array}{l}-0.136^{* * *} \\
(0.042)\end{array}$ & $\begin{array}{l}-0.142^{* * *} \\
(0.030)\end{array}$ & $\begin{array}{l}-0.136^{* * *} \\
(0.042)\end{array}$ & $\begin{array}{l}-0.142^{* * *} \\
(0.030)\end{array}$ & $\begin{array}{c}-0.135^{* * *} \\
(0.042)\end{array}$ & $\begin{array}{l}-0.142^{* * *} \\
(0.030)\end{array}$ \\
\hline Quickly Outdated & $\begin{array}{c}0.592 \\
(0.569)\end{array}$ & $\begin{array}{c}0.977^{* *} \\
(0.422)\end{array}$ & $\begin{array}{c}0.399 \\
(0.560)\end{array}$ & $\begin{array}{l}0.926^{* *} \\
(0.422)\end{array}$ & $\begin{array}{c}0.341 \\
(0.559)\end{array}$ & $\begin{array}{c}0.925^{* *} \\
(0.422)\end{array}$ & $\begin{array}{c}0.393 \\
(0.560)\end{array}$ & $\begin{array}{c}0.925^{* *} \\
(0.422)\end{array}$ \\
\hline Group (D) & $\begin{array}{l}0.196^{* *} \\
(0.080)\end{array}$ & $\begin{array}{c}-0.045 \\
(0.058)\end{array}$ & $\begin{array}{l}0.156^{* *} \\
(0.079)\end{array}$ & $\begin{array}{c}-0.049 \\
(0.058)\end{array}$ & $\begin{array}{l}0.154^{* *} \\
(0.078)\end{array}$ & $\begin{array}{c}-0.049 \\
(0.058)\end{array}$ & $\begin{array}{c}0.149^{*} \\
(0.078)\end{array}$ & $\begin{array}{c}-0.049 \\
(0.058)\end{array}$ \\
\hline East Germany (D) & $\begin{array}{c}-0.164^{* *} \\
(0.072)\end{array}$ & $\begin{array}{c}0.028 \\
(0.050)\end{array}$ & $\begin{array}{c}-0.129^{*} \\
(0.071)\end{array}$ & $\begin{array}{c}0.041 \\
(0.051)\end{array}$ & $\begin{array}{c}-0.125^{*} \\
(0.071)\end{array}$ & $\begin{array}{c}0.041 \\
(0.051)\end{array}$ & $\begin{array}{c}-0.121^{*} \\
(0.071)\end{array}$ & $\begin{array}{c}0.041 \\
(0.051)\end{array}$ \\
\hline Diversity (ln) & & $\begin{array}{l}0.179 * * * \\
(0.053)\end{array}$ & & $\begin{array}{l}0.174^{* * *} \\
(0.053)\end{array}$ & & $\begin{array}{l}0.174^{* * *} \\
(0.053)\end{array}$ & & $\begin{array}{l}0.174^{* * *} \\
(0.053)\end{array}$ \\
\hline Market Share (ln, L2) & & $\begin{array}{l}0.026^{* * *} \\
(0.006)\end{array}$ & & $\begin{array}{l}0.024^{* * *} \\
(0.006)\end{array}$ & & $\begin{array}{l}0.024^{* * *} \\
(0.006)\end{array}$ & & $\begin{array}{l}0.024^{* * *} \\
(0.006)\end{array}$ \\
\hline W_Industr & 0.000 & & 0.000 & & 0.000 & & 0.000 & \\
\hline Lambda & 0.126 & & 0.129 & & 0.124 & & 0.129 & \\
\hline Chi2 (LR test $\rho=0)$ & 2587.762 & & 705.537 & & 733.620 & & 739.943 & \\
\hline P-Value $(\rho=0)$ & 0.000 & & 0.000 & & 0.000 & & 0.000 & \\
\hline No. of Innovators & 1,461 & & 1,461 & & 1,461 & & 1,461 & \\
\hline Observations & 3,933 & & 3,933 & & 3,933 & & 3,933 & \\
\hline
\end{tabular}

Notes: The regression additionally includes a dummy variable indicating patent stock is zero. (D) denotes dummy variables. (L1) denotes one, (L2) two, and (L3) three year lagged variables, which refer to the year 2009, 2008, and 2007.

Source: ZEW: Mannheim Innovation Panel, survey 2011. 
more diverse the product portfolio of a firm, the more likely is the introduction of a product innovation. Firms with a larger market share innovate more and firms operating in an industry with quickly outdated products and services are also more likely to introduce product innovations. The differences in the propensity to innovate are also jointly significant across industries.

Given that the firm has introduced a product innovation, the commercial success with these innovations is investigated in the second stage. Column (1) of Table 3 shows the result for innovative sales. Not surprisingly, it turns out that larger as well as more productive firms are associated with higher innovation performance. With respect to the control variables, the results show, as could be expected, that the higher the innovation intensity, the higher a firm's innovation performance in terms of innovative sales. The same is true for the share of high skilled labour, which captures another important input factor for a firm's innovation activities. The introduction of a process innovation adds to the innovation performance and the patent stock shows also significantly positive effects. Surprisingly, the fact that a firm conducts $R \& D$ on a continuous basis or acquires external knowledge through external R\&D or R\&D cooperation show no significant impact. These indicators might have an influence in the earlier stage of the research and development process, but not in the commercialisation of product innovations. Firms that operate in foreign markets achieve higher sales with innovations, while firms that operate in markets where products and services are quickly outdated do not yield higher innovation success.

The results of main interest concern a firm's choice to introduce innovations under brand names onto the market. The specification presented in Column (3) includes additionally brand use as well as marketing intensity. The results show that the use of a brand has a highly significant impact on innovation performance. The market introduction of a product innovation is associated with about $24 \%$ higher sales if the firm uses a brand. Marketing intensity improves also the commercial success with product innovations. The highly significant coefficient of marketing intensity is furthermore several times higher than the coefficient for innovation intensity. Considering marketing and brand use leads to considerably smaller coefficients of innovation intensity, while the coefficient of the patent stock is also smaller and shows only slightly significant effects.

Another striking result with respect to our research question is that the probability of introducing a product innovation is associated with a firm's brand strategy. Whether a firm pursues a brand strategy is captured through a dummy variable indicating at least one registered trademark in 2007. Column (4) shows that firms which have invested in brand protection through trademark registrations in the past, are more 
likely to introduce further product innovations in the future.

Brand use can be distinguished between the use of an established brand or the use of a new brand to introduce product innovations onto the market. Column 5 presents the estimates of the specification that makes this distinction. The market introduction under an established brand shows a highly significant impact on innovation performance. This underlines the potential of an established brand to achieve awareness, the perception of desirable overall quality, and favorable associations to promote new products (Keller and Lehmann, 2006). An established brand is in this respect an important asset that is associated with about $35 \%$ larger sales with product innovations and constitutes an important competitive advantage.

Our results show on the contrary that product innovators that use a new brand for market introduction do not outperform product innovators that do not use brands for product innovation in the first three years after market introduction. Admittedly, we do not know the exact year of market introduction within the three-year period. Thus for some firms we probably measure the effect within a shorter period after market introduction. It is not surprising that the use of a new brand shows no significant association to innovation performance, since the impact from a brand arises from its degree of awareness and favourable associations of the target audience with the brand. The creation of brand awareness and positive associations takes time and an immediate impact on innovation performance cannot be taken for granted. One advantage of the use of established brands to introduce new products are lower marketing costs. A new brand, on the contrary, has to be established in the market, which might be associated with higher marketing costs. The specification in Column 7 thus includes additionally interaction terms between the use of an established brand and marketing intensity as well as between the use of a new brand and marketing intensity. Both interaction terms are not significant. I prefer therefore the specification presented in Column (5), which includes marketing intensity and distinguishes between established and new brands, but does not consider any interaction terms.

\subsection{Impact of Brand Use by Degree of Innovation}

Product innovations can be distinguished between those that are new-to-the-market and those that are not. If a product innovation is not new-to-the-market, but newto-the-firm, it is considered as an imitative product innovation. The impact of the use of a brand on the performance of a product innovation might differ between these two categories of innovativeness. Columns (1), (3), (5) of Table 4 present results for the second stage using total amount of innovative sales, sales with market novelties 
and sales with imitative products. Columns (2), (4), (6) report the corresponding first stage results (selection equation).

The results of the selection equation are quite similar for all three models and confirm prior findings from the literature. The propensity to introduce a product innovation, a market novelty or an imitative innovation increases with firm size, a firm's technological capabilities, captured through its patent stock and the proportion of high skilled labour. Furthermore, results show that older firms are less likely to introduce innovations than younger ones and the more diverse the product portfolio of a firm, the more likely is the introduction of a product innovation or imitative innovation, but surprisingly not of market novelties. Firms with a larger market share innovate more and firms operating in an industry with quickly outdated products and services are also more likely to introduce product innovations and market novelties. The differences in the propensity to innovate are also jointly significant across industries.

Table 4 shows in Column (3) the impact of brand use on the performance of market novelties. Like for product innovations, the use of a new brand has no significant effect. However, in contrast to prior findings, established brands show no significant impact for market novelties anymore. This might be explained by the higher level of uncertainty that market novelties have. It might also be the case that the reduced sample (only about half of the product innovators introduce market novelties) is too small, to obtain a significant effect. Even if the reduced sample size increases standard errors, we also observe the coefficient to be much smaller than in Column (1). Thus, the results indicate that the reputation of a firm's established brand is not easily transferable to market novelties.

Turning to imitative innovations in Column (3), the use of a new brand has still no significant effect, but the use of an established brand has a highly significant impact on the market performance of imitative product innovations and is associated with $32 \%$ larger sales with imitative products. 
Table 4: The Propensity to Innovate and Determinants of Innovation Performance

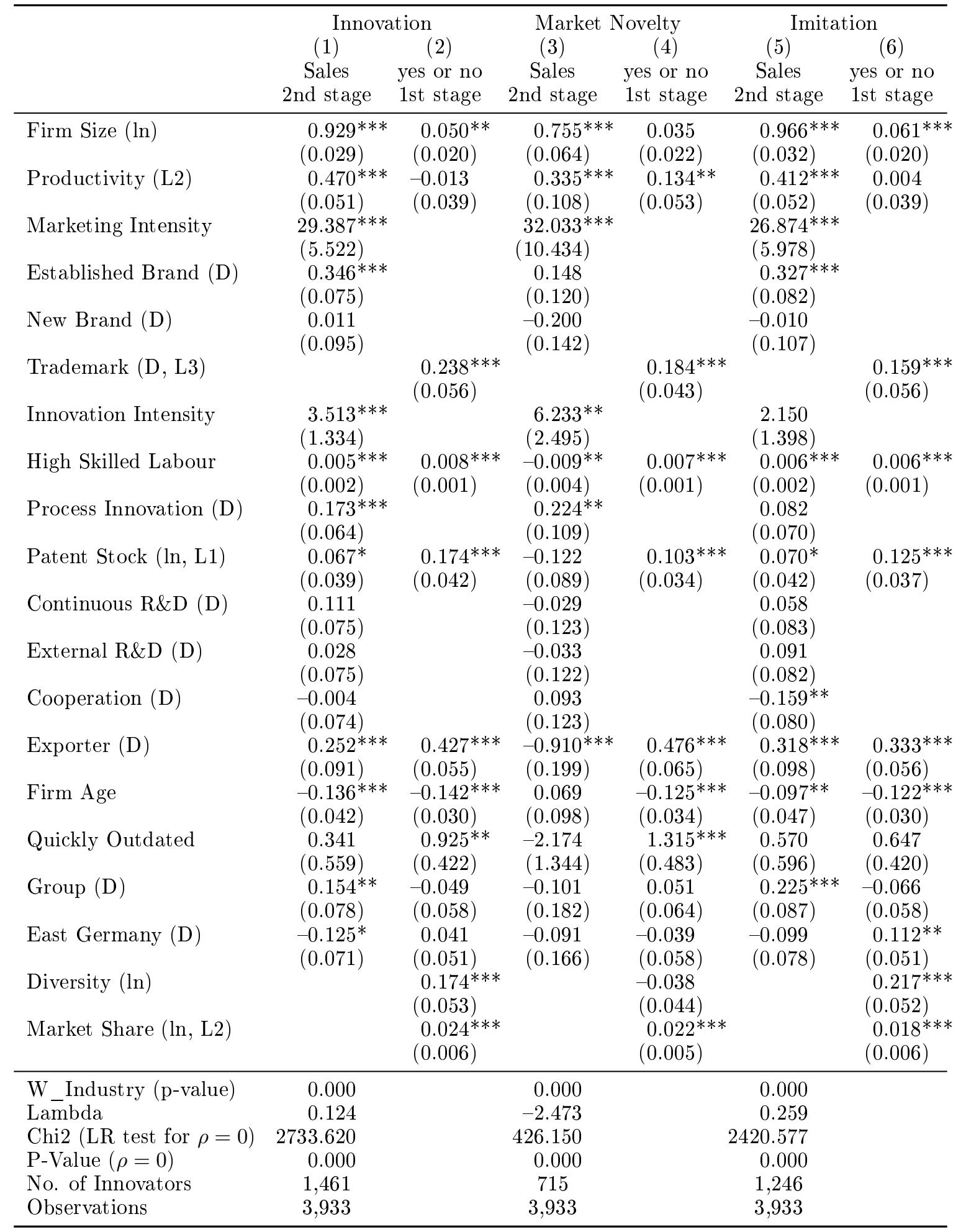

Notes: The regression additionally includes a dummy variable indicating patent stock is zero. (D) denotes dummy variables. (L2) denotes two, and (L3) three year lagged variables.

Source: ZEW: Mannheim Innovation Panel, survey 2011. 


\subsection{Impact of Brand Use by Firm Size}

The impact of brands might differ between smaller and larger firms. Larger firms might be able to establish a brand in the market more easily because of greater financial resources and better distribution channels. In order to see whether size matters for the impact of brand use, the sample is split at the median number of employees (31 employees) to investigate differences between smaller and larger firms. The split sample analysis shows that the estimates for the impact of brands on the performance of product innovations as well as on the performance with imitative products do not differ much between smaller and larger firms (see Table 9 in the Appendix). The use of an established brand is always associated with about $34 \%$ to $39 \%$ larger sales.

The differences are more striking for the performance with market novelties (see Table 5). The introduction of a market novelty under an established brand has no significant impact in the full sample, as well as in the sub-sample of larger firms, but has a significantly positive impact for the sample of smaller firms. As mentioned, one might expect the effect of established brands on the success of market novelties to be larger for large firms. However, and most strikingly, we find no impact of established brand on innovation success with new-to-market product for large firms. It is only in smaller firms, where we find a positive relationship. Smaller firms achieve with respect to these results about $39 \%$ larger sales with market novelties, provided that the market novelty is introduced under an established brand.

Furthermore, the introduction under a new brand is significantly negatively associated with the performance of market novelties for smaller firms. A smaller firm achieves about $53 \%$ less sales with market novelties. This points to the fact that the creation of a brand takes time and shows that at least in the short-run negative performance effects are possible.

Another interesting finding is that marketing activities significantly enhance performance only for larger firms. Innovation intensity and skilled labour associated with significantly higher sales with market novelties in the sample of larger but not in that of smaller firms. 
Table 5: Split Sample: Differences Between Small and Larger Firms

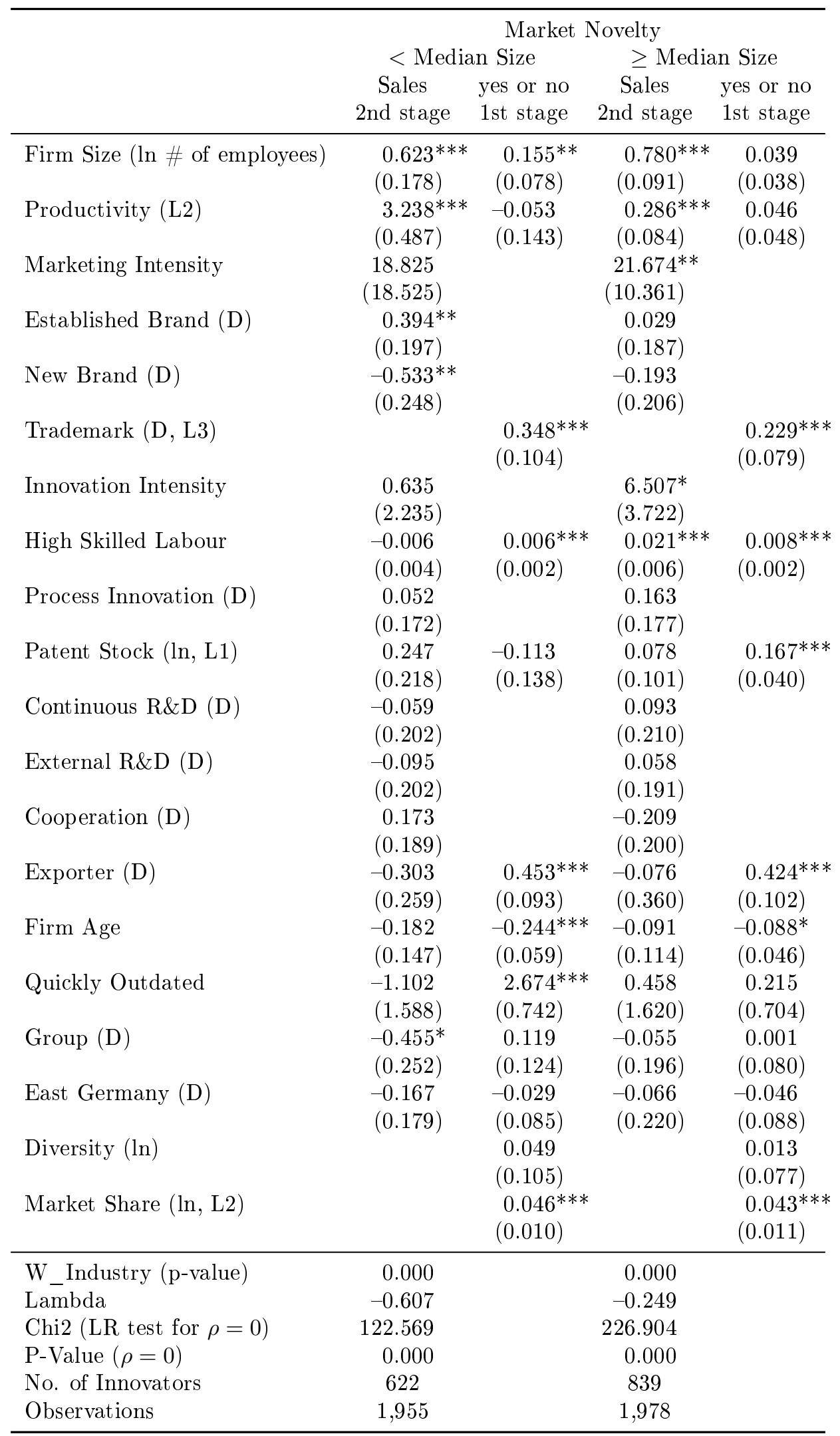

Notes: The regression additionally includes a dummy variable indicating patent stock is zero. (D) denotes dummy variables. (L2) denotes two, and (L3) three year lagged variables. Source: ZEW: Mannheim Innovation Panel, survey 2011. 


\subsection{Robustness Check}

Innovation performance is measured in 'raw values', that is, as sales with product innovations in millions of Euros. The same figure expressed as intensity, namely as share on total sales, is a widely used alternative measure for innovation performance (Crépon et al., 1998; Mairesse and Mohnen, 2002). Using the share of sales with innovations as dependent variable yields results which are properly comparable. The model specification is exactly identical to the base line model to ensure comparability. The introduction of an innovation under a new brand is again not correlated with innovation performance. An established brand, however, has a highly significant impact on the performance with product innovations, imitative innovations, as well as market novelties. The significant effect on market novelties is the most important difference to the base model. Table 10 in the Appendix provides the results in full detail.

\section{Concluding Remarks}

A firm has to decide whether it uses brand names to introduce its product innovations into the market place. Branded product innovations have the potential to achieve a higher level of awareness among the target audience, might profit from the reputation of the brand, and allow a firm to better appropriate the returns from its innovations (Aaker, 2007).

This study makes use of the German contribution to the Community Innovation Survey (CIS) to provide empirical evidence on the impact of brands on innovation performance. The 2011 survey wave provides a direct link between the introduction of a firm's product innovations and its use of a new or an established brand. This direct link could not be made through the match of trademark register data, since a firm might use an established but not trademark protected brand or it might have trademark protected brands but decides not to use them for the market introduction of the particular product innovation. The descriptive analysis shows that about $38 \%$ of product innovating firms introduce new products under a brand. About $26.5 \%$ of the firms rely on already established brands, while $14 \%$ introduce product innovations under a new brand name.

The question is whether firms are more successful with product innovations if they decide to use brands. The results suggest that branded product innovations are more successful in terms of sales with these new products. The use of an established brand is associated to remarkable $35 \%$ higher sales with product innovations. The market introduction of a product innovation under a new brand shows no significant 
effect. The empirical results could be driven by the unobservable quality of the firm's innovation, so that this can not be interpreted as causal effects.

Smaller and larger firms differ with respect to the impact of brands on the performance of market novelties. The sub-sample of smaller firms shows a significantly positive effect of the use of established brands. The use of an established brand by smaller firms is associated with about $30 \%$ larger sales with market novelties. The introduction of a market novelty by smaller firms under a new brand is however associated with significantly reduced sales of about $53 \%$.

It takes time to built a new brand. The empirical evidence provided by Crass et al. (2014) shows a positive impact of brands on overall firm performance after about four years. A positive impact of the introduction of product innovations under a new brand on innovation performance might also take time. The innovation performance is defined as a firm's sales with innovations that have been introduced into the market during the three year period 2008 to 2010. Innovation performance is directly linked to a firm's product innovation, but it captures only the immediate success. Whether product innovations are also successful in the long-run is not observable. Future research should investigate the long-run impact of the use of new and established brands on innovation performance. 


\section{References}

Aaker, D. A. (1991), Managing brand equity: capitalizing on the value of a brand name, New York: The Free Press.

Aaker, D. A. (2007), 'Innovation: Brand It or Lose It', California Management Review 50(1), 8-24.

Amara, N., Landry, R. and Traoré, N. (2008), 'Managing the protection of innovations in knowledge-intensive business services', Research Policy 37(9), 1530-1547.

Aschhoff, B., Baier, E., Crass, D., Hud, M., Hünermund, P., Köhler, C., Peters, B., Rammer, C., Schricke, E., Schubert, T. et al. (2013), Innovation in Germany - Results of the German CIS 2006 to 2010. Background report on the Innovation Surveys 2007, 2009 and 2011 of the Mannheim Innovation Panel, Zew-dokumentation 13-01, Mannheim.

Baroncelli, E., Fink, C. and Javorcik, B. K. S. (2004), The Global Distribution of Trademarks: Some Stylized Facts, World Bank Publications.

Belderbos, R., Carree, M., Diederen, B., Lokshin, B. and Veugelers, R. (2004), 'Heterogeneity in R\&D cooperation strategies', International Journal of Industrial Organization 22(8/9), 1237-1263.

Cameron, A. C. and Trivedi, P. K. (2009), Microeconometrics using STATA, Vol. 5, Stata Press College Station, TX.

Cassiman, B. and Veugelers, R. (2006), 'In Search of Complementarity in Innovation Strategy: Internal R\&D and External Knowledge Acquisition', Management Science 52(1), 68-82.

Chudnovsky, D., López, A. and Pupato, G. (2006), 'Innovation and productivity in developing countries: A study of Argentine manufacturing firms' behavior (19922001)', Research Policy 35(2), 266-288.

Cohen, W. M. and Levin, R. C. (1989), Empirical Studies of Innovation and Market Structure, in R. M. A. Schmalensee and R. D. Willig, eds, 'Handbook of Industrial Organization', Vol. 2, Elsevier, pp. 1059-1107.

Cohen, W. M. and Levinthal, D. A. (1990), 'Absorptive Capacity: A New Perspective on Learning and Innovation', Administrative Science Quarterly pp. 128-152.

Crass, D. (2014), Which Firms Use Trademarks - and Why? Reprsentative FirmLevel Evidence from Germany, mimeo. 
Crass, D., Czarnitzki, D. and Toole, A. A. (2014), The Profitability of Trademark Portfolios - Microeconometric Evidence for Germany, mimeo.

Crass, D. and Peters, B. (2014), Intangible Assets and Firm-Level Productivity, mimeo.

Crépon, B., Duguet, E. and Mairesse, J. (1998), 'Research, Innovation and Productivity: An Econometric Analysis at the Firm Level', Economics of Innovation and New Technology 7(2), 115-158.

Economides, N. (1998), 'Trademarks', The New Palgrave Dictionary of Economics and the Law (Peter Newman, Ed.) .

Eurostat (2013), Community Innovation Survey 2010: Synthesis Quality Report, Technical report, Eurostat, Luxembourg.

Garcia, R. and Calantone, R. (2002), 'A critical look at technological innovation typology and innovativeness terminology: a literature review', Journal of Product Innovation Management 19(2), 110-132.

Griffith, R., Huergo, E., Mairesse, J. and Peters, B. (2006), 'Innovation and Productivity across Four European Countries', Oxford Review of Economic Policy 22(4), 483-498.

Griffiths, W., Jensen, P. H. and Webster, E. (2011), 'What Creates Abnormal Profits?', Scottish Journal of Political Economy 58(3), 323-346.

Griliches, Z. (1979), 'Issues in Assessing the Contribution of Research and Development to Productivity Growth', The Bell Journal of Economics 10(1), 92-116.

Griliches, Z. and Mairesse, J. (1984), Productivity and R\&D at the Firm Level, in 'R \& D, Patents, and Productivity', NBER Chapters, National Bureau of Economic Research, Inc, pp. 339-374.

Grimpe, C. and Kaiser, U. (2010), 'Balancing Internal and External Knowledge Acquisition: The Gains and Pains from R\&D Outsourcing', Journal of Management Studies 47(8), 1483-1509.

Hall, B. H. (1999), Innovation and Market Value, Working Paper 6984, National Bureau of Economic Research.

Hall, B. H., Lotti, F. and Mairesse, J. (2013), 'Evidence on the Impact of R\&D and ICT Investments on Innovation and Productivity in Italian Firms', Economics of Innovation and New Technology 22(3), 300-328. 
Hall, B. and Mairesse, J. (2006), 'Empirical studies of innovation in the knowledgedriven economy', Economics of Innovation and New Technology 15(4-5), 289-299.

Hauser, J., Tellis, G. J. and Griffin, A. (2006), 'Research on Innovation: A Review and Agenda for Marketing Science', Marketing Science 25(6), 687-717.

Keller, K. L. and Lehmann, D. R. (2006), 'Brands and Branding: Research Findings and Future Priorities', Marketing Science 25(6), 740-759.

Kirk, C. P., Ray, I. and Wilson, B. (2013), 'The impact of brand value on firm valuation: The moderating influence of firm type', Journal of Brand Management 20(6), 488-500.

Klingebiel, R. and Rammer, C. (2014), 'Resource allocation strategy for innovation portfolio management', Strategic Management Journal 35(2), 246-268.

Laursen, K. and Salter, A. (2006), 'Open for innovation: the role of openness in explaining innovation performance among U.K. manufacturing firms', Strategic Management Journal 27(2), 131-150.

Leiponen, A. and Helfat, C. E. (2010), 'Innovation objectives, knowledge sources, and the benefits of breadth', Strategic Management Journal 31(2), 224-236.

Licht, G. and Stahl, H. (1997), Ergebnisse der Innovationserhebung 1996, Technical report, ZEW-Dokumentation.

Lööf, H. and Heshmati, A. (2002), 'Knowledge Capital and Performance Heterogeneity: A Firm-Level Innovation Study', International Journal of Production Economics, Elsevier 76(1), 61-85.

Mairesse, J. and Mohnen, P. (2002), 'Accounting for Innovation and Measuring Innovativeness: An Illustrative Framework and an Application', American Economic Review 92(2), 226-230.

Mairesse, J. and Mohnen, P. (2010), Using Innovations Surveys for Econometric Analysis, NBER Working Papers 15857, Cambridge, MA.

OECD, Eurostat (2005), Oslo Manual: Guidelines for Collecting and Interpreting Innovation Data, 3rd edn, Paris.

Pavitt, K. (1985), 'Patent statistics as indicators of innovative activities: Possibilities and problems', Scientometrics 7(1-2), 77-99. 
Peters, B. (2008), Innovation and Firm Performance - An Empirical Investigation for German Firms, ZEW Economic Studies 38, Heidelberg, New York.

Peters, B. and Rammer, C. (2013), Innovation panel surveys in Germany, in F. Gault, ed., 'Handbook of Innovation Indicators and Measurement', Edward Elgar Publishing, Cheltenham, UK and Northampton, MA, USA, chapter 6, pp. $135-177$.

Peters, B. and Schmiele, A. (2011), The contribution of international R\&D to firm profitability, ZEW Discussion Papers 11-002, Mannheim.

Sandner, P. G. and Block, J. (2011), 'The Market Value of R\&D, Patents, and Trademarks', Research Policy 40(7), 969-985.

Srinivasan, S., Hsu, L. and Fournier, S. (2011), 'Branding and firm value', Handbook of Marketing and Finance, Shankar Ganesan and Sunder Bharadwaj, eds., Edward Elgar Publishing .

Srinivasan, V., Park, C. S. and Chang, D. R. (2005), 'An Approach to the Measurement, Analysis, and Prediction of Brand Equity and Its Sources', Management Science 51(9), 1433-1448.

van Beers, C. and Zand, F. (2014), 'R\&D Cooperation, Partner Diversity, and Innovation Performance: An Empirical Analysis', Journal of Product Innovation Management 31(2), 292-312. 


\section{Appendix}

\section{A Definition of Variables}

Table 6: Definitions of Main Variables

\begin{tabular}{|c|c|}
\hline Variable & Definition \\
\hline Product Innovation (D) & $\begin{array}{l}\text { Dummy variable taking value } 1 \text {, if firm introduced a product innova- } \\
\text { tion during the period from } 2008 \text { to } 2010 \text {. }\end{array}$ \\
\hline $\begin{array}{l}\text { Sales with Product Innova- } \\
\text { tions }\end{array}$ & $\begin{array}{l}\text { Sales with product innovations; computed as share of sales with prod- } \\
\text { uct innovations } x \text { sales in million Euros. }\end{array}$ \\
\hline Sales Share Innovations & Share of sales with product innovations in 2010. \\
\hline Market Novelty (D) & $\begin{array}{l}\text { Dummy variable taking value } 1 \text {, if firm introduced a new-to-the mar- } \\
\text { ket innovation that a firm has introduced into the market prior to any } \\
\text { competitor ("market novelty") during the period from } 2008 \text { to } 2010 \text {. }\end{array}$ \\
\hline $\begin{array}{l}\text { Sales Share Market Novelties } \\
(\%)\end{array}$ & Share of sales with market novelties in 2010 . \\
\hline Sales Market Novelties & $\begin{array}{l}\text { Sales with market novelties; computed as share of sales with market } \\
\text { novelties } x \text { sales in million Euros. }\end{array}$ \\
\hline Imitation Product (D) & $\begin{array}{l}\text { Dummy variable taking value } 1 \text {, if firm introduced an imitative prod- } \\
\text { uct innovation during the period from } 2008 \text { to } 2010 \text {. }\end{array}$ \\
\hline $\begin{array}{l}\text { Sales Share Imitative Innova- } \\
\text { tions }(\%)\end{array}$ & $\begin{array}{l}\text { Share of sales with imitative innovations; computed as the difference } \\
\text { between the share of sales with product innovations and the share of } \\
\text { sales with market novelties. }\end{array}$ \\
\hline Sales Imitative Innovations & $\begin{array}{l}\text { Sales with imitative innovations in } 2010 \text {; computed as share of sales } \\
\text { with imitative innovations } x \text { sales in million Euros. }\end{array}$ \\
\hline Marketing Intensity & $\begin{array}{l}\text { Marketing expenditures per employee. Includes all internal and ex- } \\
\text { ternal expenditures for advertisement, reputation building, for the } \\
\text { conceptual design of marketing strategies, market and costumer re- } \\
\text { search, and the installation of new distribution channels. Pure selling } \\
\text { costs are not considered as marketing expenditures. }\end{array}$ \\
\hline Established Brand (D) & $\begin{array}{l}\text { Dummy variable taking value } 1 \text {, if firm uses an established brand to } \\
\text { introduce a product innovation into the market. }\end{array}$ \\
\hline New Brand (D) & $\begin{array}{l}\text { Dummy variable taking value } 1 \text {, if firm uses a new brand to introduce } \\
\text { a product innovation into the market. }\end{array}$ \\
\hline Trademark (D, L3) & $\begin{array}{l}\text { Dummy variable indicating firm has at least one registered trademark } \\
\text { in } 2007 \text {. }\end{array}$ \\
\hline
\end{tabular}


Table 7: Variable Definitions (continued)

\begin{tabular}{|c|c|}
\hline Variable & Definition \\
\hline Innovation Intensity & $\begin{array}{l}\text { Innovation expenditures per employee. Includes all internal } R \& D \text { and } \\
\text { external } R \& D(R \& D \text { contracted out to third parties), expenses for de- } \\
\text { sign, licenses and other external knowledge, market introduction, train- } \\
\text { ing and product preparation related to innovation. }\end{array}$ \\
\hline High Skilled Labour & Proportion of employees holding an university degree. \\
\hline Process Innovation (D) & $\begin{array}{l}\text { Dummy variable taking value } 1 \text {, if firm introduced a process innovation } \\
\text { during the previous three years. }\end{array}$ \\
\hline Patent Stock (ln, L1) & $\begin{array}{l}\text { The log of the lagged stock of patents is built up using the perpetual } \\
\text { inventory method with a constant depreciation rate of } 15 \% \text {. }\end{array}$ \\
\hline Patent Stock: zero & Dummy variable indicating firm has no patents. \\
\hline Continuous R\&D (D) & $\begin{array}{l}\text { Dummy variable taking value } 1 \text {, if firm reports to have continuous in- } \\
\text { ternal R\&D activities during } 2008-2010 \text {. }\end{array}$ \\
\hline External R\&D (D) & $\begin{array}{l}\text { Dummy variable indicating firm has contracted out } \mathrm{R} \& \mathrm{D} \text { activities to } \\
\text { third parties. }\end{array}$ \\
\hline Cooperation (D) & $\begin{array}{l}\text { Dummy variable taking value } 1 \text {, if firm reports to have innova- } \\
\text { tion/research alliances. }\end{array}$ \\
\hline Diversity (ln) & $\begin{array}{l}\text { The inverse of the share on total sales of the most important product } \\
\text { in logs. }\end{array}$ \\
\hline Market Share (ln, L2) & Market share with the most important product in 2008 in logs. \\
\hline Firm Size & Log of the number of employees in 2010. \\
\hline Productivity (L2) & Labour productivity: Sales per employee in 2008. \\
\hline Exporter (D) & Dummy variable taking value 1 , if firm reports a positive export value. \\
\hline Firm Age & Log of the number of years since the enterprise was founded. \\
\hline Quickly Outdated & $\begin{array}{l}\text { Industry average of the dummy variable taking value } 1 \text {, if firm reports } \\
\text { its products to be quickly outdated. }\end{array}$ \\
\hline Group (D) & $\begin{array}{l}\text { Dummy variable taking value } 1 \text {, if firm reports to be part of an enter- } \\
\text { prise group. }\end{array}$ \\
\hline East Germany (D) & Dummy variable taking value 1 , if firm is located in East Germany. \\
\hline
\end{tabular}




\section{B Descriptive Statistics}

Table 8: Descriptive Statistics of Main Variables

\begin{tabular}{lrrrr}
\hline & Mean & \multicolumn{1}{c}{ SD } & Min & Max \\
\hline Product Innovation (D) & 0.371 & 0.483 & 0.00 & 1.00 \\
Sales Share Innovations (\%) & 9.992 & 20.182 & 0.00 & 100.00 \\
Sales with Product Innovations & 6.406 & 77.495 & 0.00 & 2430.00 \\
Market Novelty (D) & 0.182 & 0.386 & 0.00 & 1.00 \\
Sales Share Market Novelties (\%) & 2.810 & 10.195 & 0.00 & 100.00 \\
Sales with Market Novelties & 1.400 & 14.242 & 0.00 & 453.81 \\
Imitation Product (D) & 0.317 & 0.465 & 0.00 & 1.00 \\
Sales Share Imitative Innovations (\%) & 7.182 & 16.529 & 0.00 & 100.00 \\
Sales with Product Imitations & 5.006 & 70.132 & 0.00 & 2255.80 \\
Innovation Intensity & 0.005 & 0.024 & 0.00 & 1.06 \\
High Skilled Labour (\%) & 18.344 & 23.587 & 0.00 & 100.00 \\
Process Innovation (D) & 0.286 & 0.452 & 0.00 & 1.00 \\
Patent Stock (ln, L1) & 0.002 & 0.632 & -4.55 & 8.04 \\
Patent Stock: zero & 0.883 & 0.322 & 0.00 & 1.00 \\
Continuous R\&D (D) & 0.213 & 0.410 & 0.00 & 1.00 \\
External R\&D (D) & 0.149 & 0.356 & 0.00 & 1.00 \\
Cooperation (D) & 0.213 & 0.410 & 0.00 & 1.00 \\
Marketing Intensity & 0.001 & 0.004 & 0.00 & 0.13 \\
Established Brand (D) & 0.099 & 0.299 & 0.00 & 1.00 \\
New Brand (D) & 0.052 & 0.221 & 0.00 & 1.00 \\
Trademark (D, L3) & 0.287 & 0.452 & 0.00 & 1.00 \\
Diversity (ln) & -4.187 & 0.438 & -4.61 & 0.22 \\
Missing: Diversity & 0.068 & 0.251 & 0.00 & 1.00 \\
Market Share (ln, L2) & -0.746 & 4.331 & -6.91 & 4.61 \\
Missing: Market Share (ln, L2) & 0.209 & 0.407 & 0.00 & 1.00 \\
Firm Size (ln \# of employees) & 3.676 & 1.460 & 1.61 & 10.67 \\
Productivity (L2) & 0.203 & 0.555 & 0.00 & 22.74 \\
Exporter (D) & 0.456 & 0.498 & 0.00 & 1.00 \\
Firm Age & 3.146 & 0.843 & 0.69 & 6.19 \\
Quickly Outdated & 0.061 & 0.080 & 0.00 & 0.67 \\
Group (D) & 0.284 & 0.451 & 0.00 & 1.00 \\
East Germany (D) & 0.337 & 0.473 & 0.00 & 1.00 \\
\hline & & & & \\
& & & & \\
& & & & \\
& & &
\end{tabular}

Notes: (D) denotes dummy variables. (L1), (L2), and (L3) denote one, two, and three year lagged variables which refer to the years 2009, 2008, and 2007. All Euro values are expressed in Million.

Source: ZEW: Mannheim Innovation Panel, survey 2011. 
Table 9: Split Sample: Differences between smaller and larger firms

\begin{tabular}{|c|c|c|c|c|c|c|c|c|}
\hline & \multicolumn{4}{|c|}{ Innovation } & \multicolumn{4}{|c|}{ Imitation } \\
\hline & \multicolumn{2}{|c|}{$<$ Median Size } & \multicolumn{2}{|c|}{$\geq$ Median Size } & \multicolumn{2}{|c|}{$<$ Median Size } & \multicolumn{2}{|c|}{$\geq$ Median Size } \\
\hline & Sales & yes $/$ no & $\overline{\text { Sales }}$ & yes $/$ no & Sales & yes $/$ no & $\overline{\text { Sales }}$ & yes $/$ no \\
\hline \multirow{2}{*}{ Firm Size (ln \# empl.) } & $0.815^{* * *}$ & $0.213^{* * *}$ & $1.048^{* * *}$ & $* 0.052$ & $0.953^{* * *}$ & $* 0.202^{* * *}$ & * $1.086^{* * *}$ & * $0.078^{* *}$ \\
\hline & $(0.096)$ & $(0.065)$ & $(0.049)$ & $(0.035)$ & $(0.118)$ & $(0.065)$ & $(0.058)$ & $(0.034)$ \\
\hline \multirow[t]{2}{*}{ Productivity (L2) } & $2.289^{* * *}$ & -0.137 & $0.389^{* * *}$ & * 0.002 & $2.004^{* * *}$ & $*-0.151$ & $0.356^{* * *}$ & $* 0.020$ \\
\hline & $(0.223)$ & $(0.118)$ & $(0.056)$ & $(0.046)$ & $(0.255)$ & $(0.126)$ & $(0.061)$ & $(0.046)$ \\
\hline \multirow[t]{2}{*}{ Marketing intensity } & $19.183^{*}$ & & $20.719^{* * *}$ & & 9.522 & & $19.910^{* * *}$ & \\
\hline & $(11.589)$ & & $(6.550)$ & & $(12.617)$ & & $(7.082)$ & \\
\hline \multirow{2}{*}{ Established Brand (D) } & $0.392^{* * *}$ & & $0.348^{* * *}$ & & $0.363^{* * *}$ & & $0.336^{* * *}$ & \\
\hline & $(0.107)$ & & $(0.101)$ & & $(0.120)$ & & $(0.109)$ & \\
\hline \multirow[t]{2}{*}{ New Brand (D) } & -0.057 & & 0.034 & & -0.101 & & 0.016 & \\
\hline & $(0.153)$ & & $(0.121)$ & & $(0.183)$ & & $(0.134)$ & \\
\hline \multirow[t]{2}{*}{ Trademark (D, L3) } & & $0.302^{* * *}$ & & $0.207^{* * *}$ & & $0.276^{* * *}$ & & 0.109 \\
\hline & & $(0.096)$ & & ${ }_{*}^{(0.071)}$ & & $(0.095)$ & & $*(0.071)$ \\
\hline Innovation intensity & $\begin{array}{c}-0.278 \\
(1.540)\end{array}$ & & $\begin{array}{l}8.681^{* * *} \\
(2.261)\end{array}$ & & $\begin{array}{c}-1.980 \\
(1.727)\end{array}$ & & $\begin{array}{l}7.858^{* * *} \\
(2.311)\end{array}$ & \\
\hline \multirow[t]{2}{*}{ High Skilled Labour } & 0.001 & $0.008^{* * *}$ & $0.012^{* * *}$ & $* 0.008 * * *$ & $* 0.006^{* *}$ & $0.006^{* * *}$ & * $0.009 * * *$ & $* 0.005^{* *}$ \\
\hline & $(0.002)$ & $(0.002)$ & $(0.003)$ & $(0.002)$ & $(0.003)$ & $(0.002)$ & $(0.003)$ & $(0.002)$ \\
\hline \multirow[t]{2}{*}{ Process Innovation (D) } & $0.220^{* *}$ & & $0.202^{* *}$ & & $0.192^{* *}$ & & 0.078 & \\
\hline & $(0.086)$ & & $(0.089)$ & & $(0.095)$ & & $(0.097)$ & \\
\hline \multirow{2}{*}{ Patent stock (ln) } & 0.102 & $-0.305^{* *}$ & 0.079 & $0.233^{* * *}$ & $*-0.011$ & -0.203 & 0.088 & $0.159^{* * *}$ \\
\hline & $(0.138)$ & $(0.145)$ & $(0.055)$ & $(0.045)$ & $(0.164)$ & $(0.134)$ & $(0.061)$ & $(0.040)$ \\
\hline \multirow[t]{2}{*}{ Continuous R\&D (D) } & $0.271^{* * *}$ & & 0.030 & & $0.196^{*}$ & & 0.051 & \\
\hline & $(0.103)$ & & $(0.102)$ & & $(0.115)$ & & $(0.113)$ & \\
\hline \multirow[t]{2}{*}{ External R\&D (D) } & 0.115 & & 0.006 & & 0.081 & & 0.123 & \\
\hline & $(0.111)$ & & $(0.096)$ & & $(0.125)$ & & $(0.105)$ & \\
\hline \multirow[t]{2}{*}{ Cooperation (D) } & 0.023 & & -0.037 & & -0.152 & & -0.160 & \\
\hline & $(0.101)$ & & $(0.101)$ & & $(0.111)$ & & $(0.109)$ & \\
\hline \multirow[t]{2}{*}{ Exporter (D) } & 0.028 & $0.520 * * *$ & $0.489^{* * *}$ & * $0.293^{* * *}$ & $* 0.286$ & $0.455^{* * *}$ & $* 0.518^{* * *}$ & $0.163^{*}$ \\
\hline & $(0.149)$ & $(0.077)$ & $(0.154)$ & $(0.084)$ & $(0.189)$ & $(0.078)$ & $(0.157)$ & $(0.085)$ \\
\hline Firm age & $-0.171^{* *}$ & $-0.198^{* * *}$ & $-0.128^{* *}$ & $-0.100^{* *}$ & $-0.256^{* * *}$ & $*-0.161^{* * *}$ & $*-0.072$ & $-0.088^{* *}$ \\
\hline & $(0.072)$ & $(0.046)$ & $(0.057)$ & $(0.041)$ & $(0.086)$ & $(0.046)$ & $(0.064)$ & $(0.040)$ \\
\hline Quickly Outdated & 0.436 & $1.790^{* * *}$ & 0.170 & 0.043 & 0.829 & $1.352^{* *}$ & 0.747 & -0.056 \\
\hline & $(0.758)$ & $(0.601)$ & $(0.860)$ & $(0.618)$ & $(0.863)$ & $(0.594)$ & $(0.952)$ & $(0.615)$ \\
\hline Group (D) & 0.175 & 0.036 & 0.080 & -0.043 & $0.390 * *$ & 0.001 & 0.067 & -0.057 \\
\hline & $(0.133)$ & $(0.108)$ & $(0.101)$ & $(0.071)$ & $(0.157)$ & $(0.109)$ & $(0.115)$ & $(0.071)$ \\
\hline East Germany (D) & $-0.198^{* *}$ & -0.008 & -0.030 & 0.062 & $-0.183^{*}$ & 0.076 & 0.025 & $0.129^{*}$ \\
\hline & $(0.090)$ & $(0.071)$ & $(0.108)$ & $(0.075)$ & $(0.107)$ & $(0.071)$ & $(0.123)$ & $(0.075)$ \\
\hline Diversity (ln) & & $0.143^{*}$ & & $0.188^{* * *}$ & & $0.174^{* *}$ & & $0.235^{* * *}$ \\
\hline & & $(0.085)$ & & $(0.069)$ & & $(0.085)$ & & $(0.069)$ \\
\hline Market share (ln, L2) & & $0.024^{* * *}$ & & $0.025^{* * *}$ & & $0.018^{* *}$ & & $0.016^{*}$ \\
\hline & & $(0.008)$ & & $(0.009)$ & & $(0.008)$ & & $(0.009)$ \\
\hline Size Class & & & & & & & & \\
\hline W_Industry & 0.000 & & 0.000 & & 0.000 & & 0.000 & \\
\hline Lambda & -0.080 & & 0.653 & & 0.617 & & 0.898 & \\
\hline Chi2 (LR test $\rho=0)$ & 372.725 & & 011.754 & & 272.248 & & 828.971 & \\
\hline P-Value $(\rho=0)$ & 0.000 & & 0.000 & & 0.000 & & 0.000 & \\
\hline No. of Innovators & 622 & & 839 & & 622 & & 839 & \\
\hline Observations & 1,955 & & 1,978 & & 1,955 & & 1,978 & \\
\hline
\end{tabular}

Notes: The regression additionally includes a dummy variable indicating patent stock is zero. (D) denotes dummy variables. (L2) denotes two, and(L3) three year lagged variables.

Source: ZEW: Mannheim Innovation Panel, survey 2011. 


\section{C Innovation Performance: Robustness Check}

Table 10: Innovation Success: Sales Share with Innovations

\begin{tabular}{|c|c|c|c|c|c|c|}
\hline \multirow{4}{*}{ Firm Size (ln \# of employees) } & \multicolumn{2}{|c|}{ Innovation } & \multicolumn{2}{|c|}{ Market Novelty } & \multicolumn{2}{|c|}{ Imitation } \\
\hline & Share & yes or no & Share & yes or no & Share & yes or no \\
\hline & $-1.563^{* *}$ & $0.056^{* * *}$ & $*-1.575^{* *}$ & 0.013 & -0.303 & $0.057^{* * *}$ \\
\hline & $(0.646)$ & $(0.020)$ & $(0.628)$ & $(0.023)$ & $(0.743)$ & $(0.020)$ \\
\hline Productivity (L2) & 0.495 & -0.017 & 0.567 & 0.033 & 0.252 & -0.003 \\
\hline & $(1.084)$ & $(0.039)$ & $(0.875)$ & $(0.043)$ & $(1.159)$ & $(0.040)$ \\
\hline Marketing intensity & 81.422 & & 61.060 & & 44.330 & \\
\hline & $(112.201)$ & & $(95.398)$ & & $114.680)$ & \\
\hline Established Brand (D) & $\begin{array}{l}8.269^{* * *} \\
(1.492)\end{array}$ & & $\begin{array}{l}3.145^{* *} \\
(1.548)\end{array}$ & & $\begin{array}{l}6.860^{* * *} \\
(1.527)\end{array}$ & \\
\hline New Brand (D) & 1.750 & & -0.551 & & 0.254 & \\
\hline Trademark (D, L3) & $(1.911)$ & $\begin{array}{l}0.241^{* * *} \\
(0.056)\end{array}$ & $*(1.740)$ & $\begin{array}{l}0.282^{* * *} \\
(0.062)\end{array}$ & * (2.033) & $\begin{array}{l}0.164^{* * *} \\
(0.056)\end{array}$ \\
\hline Innovation intensity & $\begin{array}{l}97.783^{* * *} \\
(27.105)\end{array}$ & & $\begin{array}{c}34.360 \\
(21.968)\end{array}$ & & $\begin{array}{c}44.469 * \\
(26.689)\end{array}$ & \\
\hline High Skilled Labour & $\begin{array}{l}0.186^{* * *} \\
(0.041)\end{array}$ & $* \begin{array}{l}0.008^{* * *} \\
(0.001)\end{array}$ & $\begin{array}{c}0.125^{* * *} \\
(0.041)\end{array}$ & $\begin{array}{l}0.007^{* * *} \\
(0.001)\end{array}$ & $\begin{array}{c}0.164^{* * * *} \\
(0.044)\end{array}$ & $\begin{array}{c}* 0.006 * * * \\
(0.001)\end{array}$ \\
\hline Process Innovation (D) & $\begin{array}{l}3.763^{* * *} \\
(1.255)\end{array}$ & & $\begin{array}{c}1.622 \\
(1.405)\end{array}$ & & $\begin{array}{l}2.574^{* *} \\
(1.268)\end{array}$ & \\
\hline Patent stock (ln) & $\begin{array}{l}2.011^{* *} \\
(0.879)\end{array}$ & $\begin{array}{l}0.170^{* * *} \\
(0.041)\end{array}$ & * $\begin{array}{c}1.487^{*} \\
(0.843)\end{array}$ & $\begin{array}{l}0.134^{* * *} \\
(0.036)\end{array}$ & $\begin{array}{c}\text { * } 1.998^{* *} \\
(1.003)\end{array}$ & $\begin{array}{l}0.129^{* * *} \\
(0.037)\end{array}$ \\
\hline Continuous R\&D (D) & $\begin{array}{c}2.789^{*} \\
(1.460)\end{array}$ & & $\begin{array}{c}1.059 \\
(1.652)\end{array}$ & & $\begin{array}{c}1.069 \\
(1.497)\end{array}$ & \\
\hline External R\&D (D) & $\begin{array}{c}-0.742 \\
(1.478)\end{array}$ & & $\begin{array}{l}-0.358 \\
(1.574)\end{array}$ & & $\begin{array}{c}-0.142 \\
(1.512)\end{array}$ & \\
\hline Cooperation (D) & $\begin{array}{l}1.017 \\
(1.453)\end{array}$ & & $\begin{array}{l}3.110^{* *} \\
(1.569)\end{array}$ & & $\begin{array}{c}-2.296 \\
(1.463)\end{array}$ & \\
\hline Exporter (D) & $\begin{array}{l}5.224^{* *} \\
(2.329)\end{array}$ & $\begin{array}{l}0.424^{* * *} \\
(0.055)\end{array}$ & $\begin{array}{c}2.505 \\
(2.442)\end{array}$ & $\begin{array}{l}0.444^{* * *} \\
(0.067)\end{array}$ & $\begin{array}{l}6.260^{* *} \\
(2.495)\end{array}$ & $\begin{array}{l}0.330^{* * *} \\
(0.056)\end{array}$ \\
\hline Firm age & $\begin{array}{l}-6.028^{* * *} \\
(0.931)\end{array}$ & $\begin{array}{c}-0.140^{* * * *} \\
(0.030)\end{array}$ & $\begin{array}{c}*-5.418^{* * *} \\
(1.006)\end{array}$ & $\begin{array}{c}* 0.141^{* * *} \\
(0.035)\end{array}$ & $\begin{array}{c}*-4.703^{* * * *} \\
(1.046)\end{array}$ & $\begin{array}{c}-0.119^{* * *} \\
(0.030)\end{array}$ \\
\hline Quickly Outdated & $\begin{array}{c}21.810^{*} \\
(11.991)\end{array}$ & $\begin{array}{l}0.863^{* *} \\
(0.420)\end{array}$ & $\begin{array}{c}-0.196 \\
(12.996)\end{array}$ & $\begin{array}{l}1.450^{* * *} \\
(0.498)\end{array}$ & $\begin{array}{c}* 21.295 \\
(13.013)\end{array}$ & $\begin{array}{c}0.644 \\
(0.419)\end{array}$ \\
\hline Group (D) & $\begin{array}{c}-1.036 \\
(1.655)\end{array}$ & $\begin{array}{l}-0.053 \\
(0.058)\end{array}$ & $\begin{array}{c}-3.032^{*} \\
(1.726)\end{array}$ & $\begin{array}{c}0.010 \\
(0.066)\end{array}$ & $\begin{array}{c}0.262 \\
(1.860)\end{array}$ & $\begin{array}{c}-0.063 \\
(0.058)\end{array}$ \\
\hline East Germany (D) & $\begin{array}{c}1.941 \\
(1.484)\end{array}$ & $\begin{array}{c}0.043 \\
(0.050)\end{array}$ & $\begin{array}{c}-2.880^{*} \\
(1.625)\end{array}$ & $\begin{array}{c}-0.024 \\
(0.060)\end{array}$ & $\begin{array}{l}3.980^{* *} \\
(1.681)\end{array}$ & $\begin{array}{l}0.109^{* *} \\
(0.051)\end{array}$ \\
\hline Diversity $(\ln )$ & & $\begin{array}{l}0.173^{* * *} \\
(0.053)\end{array}$ & & $\begin{array}{c}0.027 \\
(0.062)\end{array}$ & & $\begin{array}{l}0.204^{* * *} \\
(0.052)\end{array}$ \\
\hline Market share (ln, L2) & & $\begin{array}{l}0.023^{* * *} \\
(0.006)\end{array}$ & & $\begin{array}{l}0.043^{* * *} \\
(0.007)\end{array}$ & & $\begin{array}{l}0.017^{* * *} \\
(0.006)\end{array}$ \\
\hline $\mathrm{W}$ Industry & 0.000 & & 0.000 & & 0.000 & \\
\hline Lambda & 18.216 & & 8.504 & & 25.719 & \\
\hline Chi2 (LR test for $\rho=0)$ & 258.232 & & 139.145 & & 124.711 & \\
\hline P-Value $(\rho=0)$ & 0.000 & & 0.000 & & 0.000 & \\
\hline No. of Innovators & 1,478 & & 716 & & 1,246 & \\
\hline Observations & 3,950 & & 3,950 & & 3,950 & \\
\hline
\end{tabular}

Notes: The regression additionally includes a dummy variables indicating patent stock is zero. Source: ZEW: Mannheim Innovation Panel, survey 2011. 